DOI: https://doi.org/10.47405/mjssh.v6i5.793

\begin{tabular}{|c|c|}
\hline$\sum_{i=1}$ & Malaysian Journal of Social Sciences and Humanities (MJSSH) \\
\hline $\begin{array}{l}\text { Malaysian Journal of } \\
\text { Solcial cciences and }\end{array}$ & Volume 6, Issue 5, May 2021 \\
\hline (MJ-SSH) & e-ISSN : 2504-8562 \\
\hline & $\begin{array}{l}\text { Journal home page: } \\
\text { www.msocialsciences.com }\end{array}$ \\
\hline
\end{tabular}

\title{
Pembinaan dan Pengesahan Soal Selidik Penerimaan Pelaksanaan Elemen Pendidikan STEM dalam Pengajaran dan Pembelajaran Guru
}

\author{
Mohammad Azri Bin Amatan ${ }^{1}$, Crispina Gregory K Han ${ }^{2}$, Vincent Pang ${ }^{2}$ \\ ${ }^{1}$ SMK Likas, Kota Kinabalu, Sabah \\ ${ }^{2}$ Fakulti Psikologi Pendidikan, Universiti Malaysia Sabah (UMS)
}

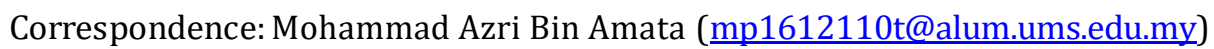

\begin{abstract}
Abstrak
Tujuan kajian ini adalah untuk membangunkan dan mengesahkan Soal Selidik Penerimaan Pelaksanaan Elemen Pendidikan STEM dalam Pengajaran dan Pembelajaran Guru dari perspektif guru sebagai pelaksana di Sekolah Menengah. Berdasarkan penerokaan literatur, konstruk dan item yang dikenal pasti menyumbang kepada pelaksanaan elemen STEM dalam pengajaran dan pembelajaran dari aspek penerimaan guru berjaya dibangunkan. Soal Selidik telah disahkan melalui kesahan muka dan kesahan kandungan instrumen yang melibatkan 13 orang pakar manakala, kesahan konstruk dan kebolehpercayaan instrumen di analisis menggunakan perisian Statistical Package of Social Science (SPSS) Versi 25.0. Seramai 825 orang guru sekolah menengah terlibat dalam kajian ini. Muatan faktor bagi setiap item berada dalam julat 0.562 hingga 0.799 , manakala keputusan analisis kebolehpercayaan adalah, $a=0.974$. Keputusan menunjukkan instrumen mempunyai kesahan dan kebolehpercayaan yang tinggi dan sesuai diaplikasikan dalam kajian sebenar.
\end{abstract}

Kata kunci: kesahan, kebolehpercayaan, elemen pendidikan STEM, pengajaran dan pembelajaran

\section{Construction and Validation of Element Implementation Acceptance Questionnaire STEM Education in Teacher Teaching and Learning}

\begin{abstract}
The purpose of this study is to develop and validate the Questionnaire on the Acceptance of the Implementation of STEM Education Elements in Teacher Teaching and Learning from the perspective of teachers as implementers in Secondary Schools. Based on the literature reviewed, constructs and items that have been identified contributing to the implementation of STEM elements in teaching and learning from the aspect of teacher acceptance were successfully developed. The Questionnaire went through face validation and content validity which involving 13 experts meanwhile, the construct validity and reliability of the instrument were analyzed using Statistical Package of Social Science (SPSS) Version 25.0. A total of 825 secondary school teachers were involved in this study. The factor loading for each item was in the range of 0.562 to 0.799 , while the results of the reliability analysis were, $\mathrm{a}=0.974$. The results show that the instrument has high validity and reliability and it is suitable to be applied in the actual study.
\end{abstract}

Keywords: validity, reliability, STEM education element, teacher teaching and learning 


\section{Pengenalan}

Sistem pendidikan perlu berubah agar sentiasa releven dengan tuntutan semasa (Dede, 2010). Dalam usaha melonjakkan lagi wawasan Malaysia ke arah menjadi negara maju berpendapatan tinggi, penggubalan Dasar Sains, Teknologi dan Inovasi Negara (DSTIN) yang pada mulanya diperkenalkan pada 1986 telah berkembang turut menunjangi bidang Pendidikan STEM, selain disokong melalui Dasar 60 peratus sains dan 40 peratus sastera (Dasar 60:40) sejak tahun 1967. Penggubalan dasar ini selari dengan strategi dalam pendidikan STEM itu sendiri, yang mana bermatlamat melonjakkan pembangunan negara melalui pengaplikasian bidang ilmu sains, teknologi dan inovasi sebagai mekanisme kemajuan yang dapat memenuhi tuntutan persaingan pada era globalisasi. Oleh itu, KPM melalui PPM 2013-2025 yang digubal berteraskan tiga misi utama, iaitu pertama, usaha pemahaman terhadap pencapaian dan cabaran dunia pendidikan semasa dengan memberi tumpuan kepada aspek pendidikan, meninggikan kualiti, kesamarataan akses dan perpaduan nasional melalui strategi pengoptimuman kelancaran sistem. Kedua, mencipta visi dan aspirasi jangka panjang khususnya dalam menambah baik sistem pendidikan negara dan yang ketiga, menjadi panduan terhadap usaha penyusunan program transformasi menyeluruh sistem pendidikan negara.

\section{Sorotan Literatur}

Tahap penerimaan rakyat Malaysia yang masih berada pada aras lemah masih membelenggu pelaksanaan pendidikan STEM di negara Malaysia (Malaysian Science and Technology Information Centre (MASTIC), 2008; Organisation for Economic Co-operation and Development (OECD), 2012; KPM, 2013; Yusof et al., 2012). Hal ini memberi dampak terhadap statistik yang menunjukkan pola menurun ketara penyertaan pelajar dalam bidang STEM. Curriculum Development Division (2016) menyebutkan sehingga tahun 2014, didapati sekitar 21 peratus pelajar di seluruh negara mempunyai kecenderungan dalam bidang STEM jika dibandingkan dengan sejumlah 79 peratus pelajar yang lebih ke arah bidang lain. Enrolmen pelajar yang mengikuti bidang STEM peringkat menengah atas hanya berada pada paras 45.7 peratus berbanding sasaran 46 peratus pada tahun 2018 (KPM, 2018; Nur dan Tuan, 2018). Kesannya, pada masa ini negara masih mengalami kekurangan sumber buruh khususnya dalam bidang teknikal dan vokasional. Situasi ini bertambah buruk, apabila wujud trend pelajar di peringkat sekolah menengah semakin mengetepikan subjek STEM dalam pemilihan pakej mata pelajaran yang mereka ambil. Pelajar dilihat sudah semakin kurang menunjukkan minat terhadap bidang STEM (Noraini Idris, 2019). Keadaan ini disumbangkan oleh faktor kurang kesedaran terhadap potensi bidang kerjaya STEM (KPM, 2013), kurang pendedahan terhadap ilmu berkaitan bidang STEM (Roehrig et al., 2012), kurang usaha menggiatkan latihan profesional tentang pendidkan STEM (Johnson \& Sondergeld, 2016) dan kurang pengintegrasian dan pengaplikasian pendidikan STEM yang konkrit dalam kehidupan (Bunyamin \& Finley, 2016). Oleh itu Siew et al. (2015) menegaskan perlunya institusi pendidikan khususnya melalui tenaga pengajar seperti para guru memainkan peranan signifikan dalam pelaksanaan kurikulum pendidikan STEM selaras PPPM 2013-2025, apatah lagi inisiatif pendidikan STEM yang sepatutnya pada masa kini berada pada gelombang kedua dan ketiga pelaksanaan iaitu dalam domain penyemakan semula kurikulum sedia ada dan pelaksanaan kurikulum baharu. Bagi National STEM Movement, wujud masalah penerimaan guru-guru khususnya daripada kelompok pihak pengurusan sekolah terhadap pendidikan STEM di Malaysia. Masih wujud isu pihak pengurusan sekolah bersikap negatif terhadap perubahan yang menyebabkan wujud keadaan di mana guru tidak mendapat kerjasama yang baik disebabkan antara lain kerenah birokrasi pihak pengurusan sekolah (Berita Harian, 17 Mac 2019). Keadaan ini jika tidak ditangani boleh memberikan kesan buruk terhadap keupayaan negara bersaing dalam penyediaan sumber manusia profesional khususnya dalam bidang STEM. Mengambil kira permasalahan yang telah dibincangkan, timbul persoalan iaitu sejauh mana pelaksanaan pendidikan STEM yang dirancang dapat diterima oleh guru sebagai pelaksana kurikulum pendidikan STEM di sekolah. Justeru, usaha membangunkan instrumen ini menepati keperluan keadaan semasa, disamping sebagai sumbangan kecil pengkaji dalam merungkai keadaan sebenar pelaksanaan elemen pendidikan STEM di sekolah. Instrumen ini berguna sebagai petunjuk kepada pihak berkepentingan dalam menangani permasalahan yang berlaku. 


\section{Tujuan Kajian}

Kajian ini bertujuan untuk menguji kesahan dan kebolehpercayaan Soal Selidik Penerimaan Pelaksanaan Elemen Pendidikan STEM dalam Pengajaran dan Pembelajaran Guru (SSPG-STEM) yang telah dibangunkan.

\section{Metod Kajian}

Kajian ini menggunakan reka bentuk kajian kuantitatif iaitu jenis tinjauan. Penyelidik telah mengedarkan borang soal selidik melibatkan 825 orang guru dari tujuh buah Pejabat Pendidikan Daerah (PPD) di Negeri Sabah, iaitu PPD Kota Kinabalu, PPD Penampang, PPD Kudat, PPD Kunak, PPD Lahad Datu, PPD Semporna dan PPD Sandakan yang dikenal pasti telah melaksanakan penerapan elemen pendidikan STEM dalam PdP. Lokasi kajian ditentukan dengan mengambil kira kesesuaian instrumen agar releven ditadbir kepada guru-guru di sekolah terlibat. Pengkaji menggunakan teknik pensampelan berstrata berkadar dan memilih sampel secara rawak mudah, iaitu bagi memungkinkan kebarangkalian setiap populasi dipilih daripada setiap kumpulan atau strata terlibat. Pengkaji mendapat kerjasama baik daripada pihak JPN Sabah, PPD, pentadbir sekolah serta guru-guru di sekolah terlibat. Selanjutnya, sebelum borang soal selidik ditadbir, pautan 'google forms' borang soal selidik beserta panduan dan arahan disediakan dan dijelaskan kepada pihak pentadbir dan guru-guru di sekolah berkenaan. Selanjutnya, hasil pengisian borang soal selidik pada pautan yang disediakan, pengkaji berjaya memperolehi sebanyak 825 set lengkap, iaitu melebihi jumlah minimum saiz responden mengikut ketetapan Chua (2014).

\section{Instrumen Soal Selidik}

Instrumen kajian yang dibina, iaitu Soal Selidik Penerimaan Pelaksanaan (SSPG-STEM) terdiri daripada 31 item. Soal selidik ini menggunakan jenis skala Likert lima mata (Jadual 1). Soal selidik penerimaan pelaksanaan melibatkan sub-konstruk kepercayaan, komitmen dan sikap guru.

$$
\text { Jadual 1: Penggunaan Skala Likert Lima Mata }
$$

\begin{tabular}{clll}
\hline Mata & \multicolumn{1}{c}{ Tafsiran } & \multicolumn{1}{c}{ Sub-Konstruk } & \multicolumn{1}{c}{ Sumber } \\
\hline 1 & Sangat Tidak Setuju - Strongly Disagree & & \\
2 & Tidak Setuju - Disagree & - Kepercayaan Guru & \\
3 & Tidak Pasti Setuju atau Tidak Setuju - & - Sikap Guru & Likert (1932) \\
& Neither Agree nor Disagree & - Komitmen Guru & \\
4 & Setuju - Agree & & \\
5 & Sangat Setuju - Strongly Agree & & \\
\hline
\end{tabular}

\section{Prosedur Pembangunan Instrumen}

Dalam konteks kajian ini pengkaji mengaplikasikan prosedur pembangunan instrumen berdasarkan Walker \& Fraser (2005), iaitu;

\section{Peringkat Pertama - Mengenal Pasti Konstruk Utama}

Kajian literatur dilakukan dengan meneroka pelbagai sumber rujukan seperti jurnal dan artikel daripada kajian-kajian terdahulu sama ada dari dalam mahupun luar negara. Langkah ini penting untuk mengenal pasti konsep dan komponen utama yang berkaitan dengan konteks kajian. Selain itu, pengkaji meneroka instrumen-instrumen berkaitan yang pernah dibina sebelum ini. Tujuannya adalah untuk mengetahui konstruk dan item yang telah dibina. Hal ini penting kerana sekiranya terdapat konstruk atau item yang bersesuaian, ia boleh diubahsuai mengikut kesesuaian konteks kajian ini. Seterusnya, proses memperoleh maklumat, pendapat dan idea berkaitan daripada panel pakar berkaitan 
DOI: https://doi.org/10.47405/mjssh.v6i5.793

dilakukan bagi pemilihan dan penentuan konstruk utama berdasarkan tinjauan literatur, instrumen sedia ada dan perbincangan pakar. Berdasarkan usaha penerokaan literatur, dirumuskan perincian konstruk soal selidik yang digunakan seperti dalam Jadual 2 .

Jadual 2: Penentuan Konstruk SSPG-STEM

\begin{tabular}{ccc}
\hline Konstruk & $\begin{array}{c}\text { Sub-Konstruk } \\
\text { Yang Diukur }\end{array}$ & Sumber \\
\hline
\end{tabular}

Penerimaan

Pelaksanaan Elemen

Pendidikan

STEM Dalam PdP Guru
Kepercayaan Guru Terhadap

Pelaksanaan Elemen Pendidikan STEM

Sikap Guru Terhadap Pelaksanaan Elemen Pendidikan STEM

Komitmen Guru Terhadap Pelaksanaan Elemen Pendidikan STEM
Fishbein \& Ajzen (1975), Fishbein \& Ajzen (1980), Ajzen (1991;2006), Hall \& Hord (2001), Shepard (2000), Law (2008), Tan (2010), Shumow \& Miller (2001), Pryoe et al., (2015), Copriady (2014), Chiu et al., (2015), Suresh Kumar (2011), Nadelson et al., (2012), Han et al., (2015), Tschannen-Moran (2003), Misha (1996), Lokman et al., (2010), Kulbertis (2006), Azodi (2006), Strike (2007), KPM (2013), Syed Ismail (2013), Thorndike (1997), Colemen (1990), Cohen (1990), Earnest (1989), Constant et al., (1994), Rosezalvia Dennis (1996), Thompson (1992), Guskey (2002), Kulkarni et al., (2006), Rosli (2008), Adnan \& Zakaria (2019), Fives \& Buehl (2012), Fives \& Buehl, 2014), Kagan (1992), Bekiroglu (2009), Alkharusi (2009), Panduan Pelaksanaan STEM dalam PdP (BPK, 2016), Noorzeliana Idris (2016), Lokman \& Hamidon (2007), Ajzen \& Fishbein (2000), Reio (2005), Tan (2010), Tang et al., (2015), Zulkifli \& Raja (1994), Khuzaimah \& Shahlan (2019), Hurlock (1978), Siti \& Suguneswary (2016), Fullan \& Mascall (2000), Frey \& Fisher (2004), Demetriadis et al., (2003), Abdul Zubir (2007), Radin (2008)

Fishbein \& Ajzen (1975), Stufflebeam (1987;2001), Rummers \& Gage (1987), Ramlah (1993), Taha (1977), Zimbardo \& Leippe (1991), MASTIC (2008), OECD (2014), KPM (2013), Yusof et al., (2012), Mohammad Azri \& Crispina (2019), Noraini \& Suhaida (2014), Stenhouse (1984), Stiggins (2005), Noorzeliana Idris (2016), Shepard (2000), Radin (2008), Abdul Zubir (2007)

Fishbein dan Ajzen (1975), Shepard (2000), Hall \& Hord (2001), Law (2008), Tan (2010), Miller et al., (2009), KPM, (2016), Noradzimah \& Harizon (2017), Zul Aizam Yassin et al., (2017), Che Mas Saud et al., (2017), Hamzah \& Sinnasamy (2009), Nur Amelia \& Lilia., (2019), Stenhouse (1975), Olson (2000), Kelly (1982), Rudduck (1995), Blenkin et al., (1992), Fullan (2001), Mohd Nasaruddin (2006), Rohani et al., (2010), Louis, (1998), Radin (2008) 


\section{Peringkat Kedua - Pembinaan Item dalam Setiap Konstruk}

Peringkat kedua melibatkan pembinaan item dalam setiap konstruk dengan mengadaptasi item yang bersesuaian daripada instrumen sedia ada untuk dimasukkan sebagai item dalam instrumen baru. Selain itu, item-item baru juga dibina berdasarkan literatur dan perbincangan untuk setiap konstruk yang dikenalpasti. Sehubungan dengan itu, kesahan pakar yang berpengalaman luas dalam bidang kajian telah dilaksanakan (Jadual 3). Kesahan instrumen melalui semakan pakar bermanfaat dilakukan terutamanya dalam mengesahkan kesesuaian item, kesepadanan konstruk dan keserasian skala pengukuran dalam borang soal selidik yang dibina. Jadual 4 memperincikan penentuan taburan item soal selidik.

Jadual 3: Senarai Panel Pakar Kajian

\begin{tabular}{|c|c|c|c|}
\hline Panel Pakar & $\begin{array}{l}\text { Bidang } \\
\text { Kepakaran } \\
\end{array}$ & $\begin{array}{l}\text { Institusi / } \\
\text { Jawatan }\end{array}$ & Pengalaman \\
\hline Prof. Dr. A (Pakar 1) & Pendidikan STEM & National STEM Movement & 30 Tahun \\
\hline Prof. Dr. B (Pakar 2) & Statistik dan Kuantitatif & $\begin{array}{l}\text { Pusat Pengajian Sains, } \\
\text { FPP, UNISZA }\end{array}$ & 32 Tahun \\
\hline Prof. Dr. C (Pakar 3) & Pendidikan Sains & $\begin{array}{l}\text { Pensyarah Kanan FPP, } \\
\text { UMS }\end{array}$ & 30 Tahun \\
\hline $\begin{array}{l}\text { Prof. Madya Dr. D } \\
\text { (Pakar 4) }\end{array}$ & Pendidikan STEM & $\begin{array}{l}\text { Pensyarah Kanan FPP, } \\
\text { UMS }\end{array}$ & 30 Tahun \\
\hline $\begin{array}{l}\text { Prof. Madya Dr. E } \\
\text { (Pakar 5) }\end{array}$ & Pendidikan STEM & Pusat Asasi, STEM, UMT & 30 Tahun \\
\hline Dr. F (Pakar 6) & $\begin{array}{l}\text { Pendidikan Matematik dan } \\
\text { Sains }\end{array}$ & $\begin{array}{l}\text { Pensyarah Kanan, Jabatan } \\
\text { Sains Matematik, UM }\end{array}$ & 10 Tahun \\
\hline Dr. G (Pakar 7) & $\begin{array}{l}\text { Pendidikan Sains dan } \\
\text { Teknikal }\end{array}$ & $\begin{array}{l}\text { Pensyarah Kanan, } \\
\text { Jabatan Sains Teknikal, } \\
\text { UPM }\end{array}$ & 21 Tahun \\
\hline Dr. H (Pakar 8) & $\begin{array}{l}\text { Pendidikan } \\
\text { STEM }\end{array}$ & $\begin{array}{l}\text { Guru Kanan Bidang STEM } \\
\text { SMK Likas }\end{array}$ & 10 Tahun \\
\hline Dr. I (Pakar 9) & $\begin{array}{l}\text { Pendidikan STEM, } \\
\text { Pembanguan Soal Selidik }\end{array}$ & $\begin{array}{l}\text { Guru KananBidang STEM, } \\
\text { SK Pengkalan Tentera } \\
\text { Darat }\end{array}$ & 12 Tahun \\
\hline Dr. J (Pakar 10) & $\begin{array}{l}\text { Pendidikan STEM, } \\
\text { Pembangunan } \\
\text { Model STEM }\end{array}$ & $\begin{array}{l}\text { Pensyarah Kanan, Fakulti } \\
\text { Pendidikan } \\
\text { UiTM }\end{array}$ & 12 Tahun \\
\hline Dr. K (Pakar 11) & $\begin{array}{l}\text { Statistik, } \\
\text { Pembanguan } \\
\text { Soal Selidik }\end{array}$ & $\begin{array}{l}\text { Pensyarah Kanan, EiMAS, } \\
\text { UKM }\end{array}$ & 19 Tahun \\
\hline Dr. L (Pakar 12) & $\begin{array}{l}\text { Statistik, Pengukuran dan } \\
\text { Penilaian }\end{array}$ & $\begin{array}{l}\text { Pensyarah Kanan, Fakulti } \\
\text { Pendidikan, UKM }\end{array}$ & 38 Tahun \\
\hline Dr. M (Pakar 13) & $\begin{array}{l}\text { Statistik, Pengukuran dan } \\
\text { Penilaian }\end{array}$ & $\begin{array}{l}\text { Pensyarah Kanan } \\
\text { Jabatan Asas Pendidikan } \\
\text { dan Kemanusiaan } \\
\text { Fakulti Pendidikan, UM }\end{array}$ & 29 Tahun \\
\hline
\end{tabular}

Instrumen yang telah disemak oleh pakar ini kemudiannya dianalisis dan dibuat penelitian semula berdasarkan komen serta cadangan penambahbaikan yang telah diberikan. Segala komen dan cadangan yang diperoleh diambil kira dan penambahbaikan dilakukan ke atas item-item dalam pembinaan instrumen. Selanjutnya, kajian rintis dijalankan bagi menentukan aspek kesahan dan kebolehpercayaan instrumen yang dibina. 


\begin{tabular}{ccccccc}
\hline Konstruk & $\begin{array}{c}\text { Bil. } \\
\text { Item }\end{array}$ & $\begin{array}{c}\text { No. } \\
\text { Item }\end{array}$ & $\begin{array}{c}\text { Adopt } \\
(\sqrt{ })\end{array}$ & $\begin{array}{c}\text { Adapt } \\
(\sqrt{ })\end{array}$ & $\begin{array}{c}\text { New } \\
(\sqrt{ })\end{array}$ & Sumber \\
\hline
\end{tabular}

Fishbein \& Ajzen (1975), Fishbein \& Ajzen (1980), Ajzen (1991;1992;2006), Hall \& Hord (2001), Shepard (2000), Law (2008), Tan (2010), Shumow \& Miller (2001), Pryoe et al., (2015),

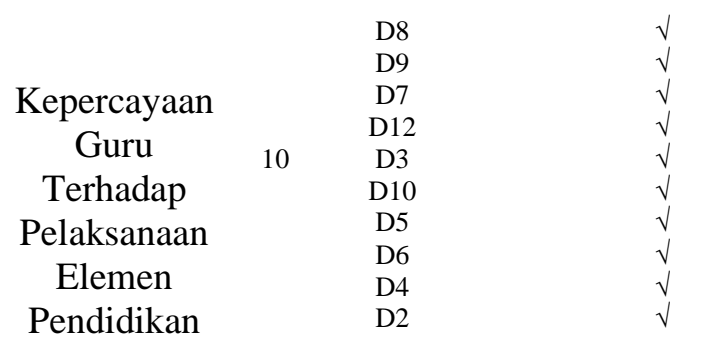
Copriady (2014), Chiu et al., (2015), Suresh Kumar (2011), Nadelson et al., (2012), Han et al., (2015), Tschannen-Moran (2003), Misha (1996), Lokman et al., (2010), Kulbertis (2006), Azodi (2006), Strike (2007), KPM (2013), Syed Ismail (2013), Thorndike (1997), Colemen (1990), Cohen (1990), Earnest (1989), Constant et al., (1994), Rosezalvia Dennis (1996), Thompson (1992), Guskey (2002), Kulkarni et al., (2006), Rosli (2008), Adnan \& Zakaria (2019), Fives \& Buehl (2012), Fives \& Buehl, 2014), Kagan (1992), Bekiroglu (2009), Alkharusi (2009), Panduan Pelaksanaan STEM dalam PdP (BPK, 2016), Noorzeliana Idris (2016), Lokman \& Hamidon (2007), Ajzen \& Fishbein (2000), Reio (2005), Tan (2010), Tang et al., (2015), Zulkifli \& Raja (1994), Khuzaimah \& Shahlan (2019), Hurlock (1978), Siti \& Suguneswary (2016), Fullan \& Mascall (2000), Frey \& Fisher (2004), Demetriadis et al., (2003), Abdul Zubir (2007), Radin (2008)

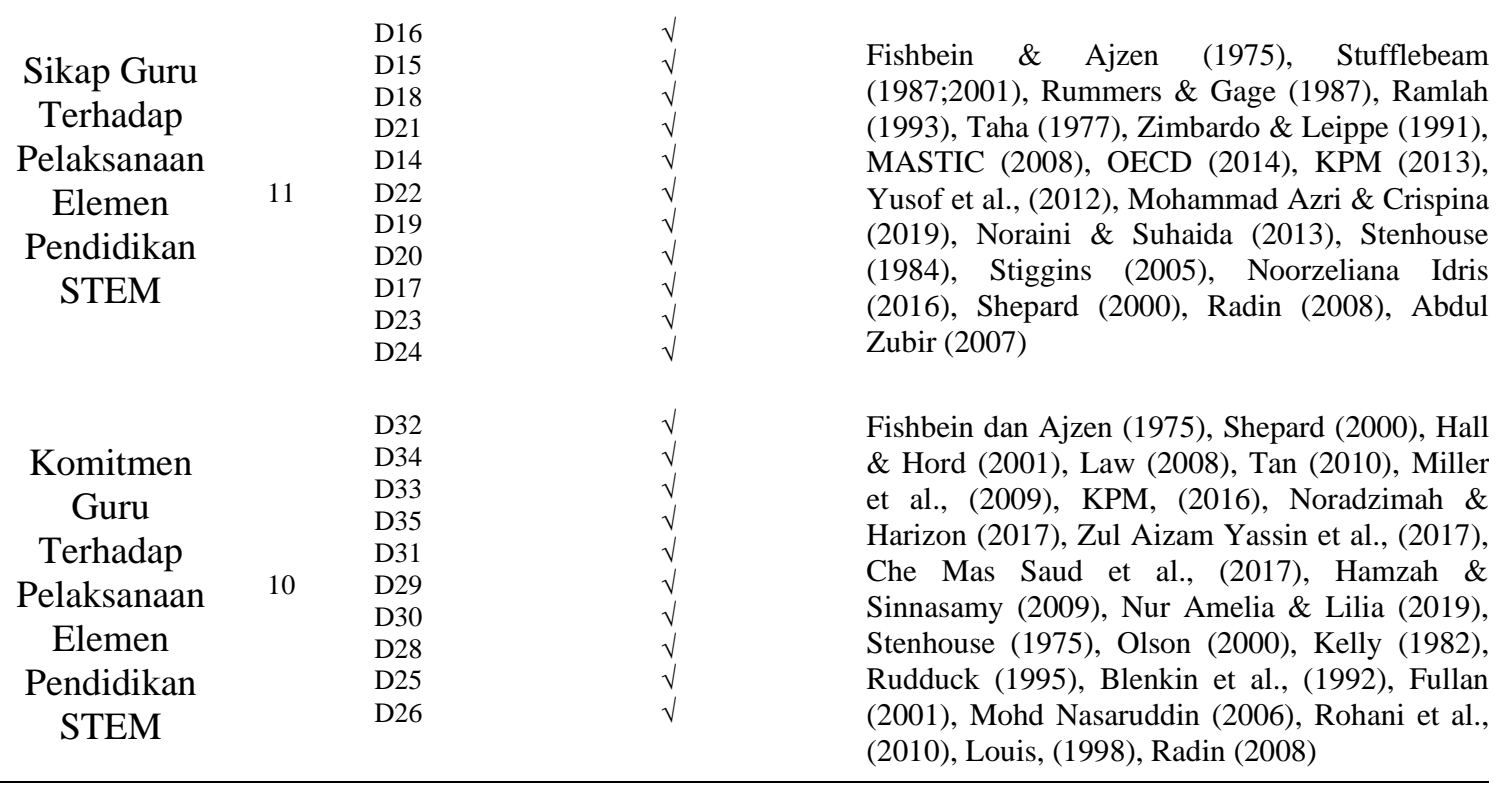

\section{Peringkat Ketiga - Menjalankan Kajian Sebenar}

Peringkat ketiga melibatkan pentadbiran instrumen yang telah dibina pada sampel yang lebih besar bagi meningkatkan lagi kesahan dan kebolehpercayaan instrumen. Setelah meneliti tujuan pembinaan item yang dihasilkan ini, penyelidik menetapkan untuk memperoleh kesahan konstruk dengan diperkukuhkan lagi dengan bentuk kesahan yang lain iaitu kesahan muka dan kesahan kandungan. Nunally (1967) menyatakan kesahan konstruk lebih sesuai dan wajar untuk digunakan bagi mengesahkan instrumen yang dibangunkan berbanding prosedur lain. Justeru, dalam konteks kajian ini pengkaji menggunakan kaedah Analisis Faktor Penerokaan (EFA) bagi mengesahkan pembinaan konstruk dan item yang telah dibentuk. 


\section{Hasil Kajian}

\section{Ujian Kenormalan Kajian Rintis}

Ujian kenormalan taburan data kajian rintis dilakukan ke atas Soal Selidik Penerimaan Pelaksanaan Elemen Pendidikan STEM dalam PdP Guru. Penentuan normaliti data diukur melalui kriteria nilai kepencongan (skewness) dan kecerunan (kurtosis), berdasarkan indikator julat nilai -1 dan 1 (Tabachnick \& Fidell, 2007; Hair et al., 2010). Hasil analisis mendapati, nilai skewness dan kurtosis soal selidik adalah normal (Jadual 5).

Jadual 5: Keputusan Ujian Taburan Normaliti Kajian Rintis

\begin{tabular}{llllll}
\hline & $\begin{array}{l}\text { N } \\
\text { Statistic }\end{array}$ & $\begin{array}{l}\text { Skewness } \\
\text { Statistic }\end{array}$ & Std. Error & $\begin{array}{l}\text { Kurtosis } \\
\text { Statistic }\end{array}$ & Std. Error \\
\hline $\begin{array}{l}\text { Penerimaan Pelaksanaan } \\
\begin{array}{l}\text { Elemen Pendidikan STEM } \\
\text { dalam PdP Guru }\end{array}\end{array}$ & 825 & -.297 & .085 & .871 & .170 \\
\hline
\end{tabular}

\section{Keputusan Analisis Faktor Penerokaan (EFA)}

Analisis faktor dijalankan menggunakan kaedah Extraction of Principal Component dengan Varimax Rotation ke atas setiap item yang mengukur konstruk penerimaan pelaksanaan elemen pendidikan STEM dalam PdP Guru. Nilai signifikan bagi sukatan kecukupan pensampelan Kaiser-Meyer-Olkin (KMO) dan nilai Ujian Kesferaan Bartlett diteliti sebelum analisis faktor dijalankan. Kaiser (1974) menetapkan nilai KMO >0.5 dan nilai ujian kesferaan Bartlett yang cukup besar menunjukkan suatu data memenuhi syarat kebolehfaktoran. Keputusan analisis dalam Jadual 6 menunjukkan nilai signifikan bagi ujian KMO dan Ujian Kesferaan Bartlett kajian ini. Keputusan menunjukkan data ini memenuhi syarat kebolehfaktoran untuk melaksanakan analisis faktor.

Jadual 6: Nilai Kaiser Meyer Olkin dan Signifikan Konstruk

\begin{tabular}{|c|c|c|c|c|c|}
\hline \multirow{2}{*}{ Konstruk } & \multirow{2}{*}{$\begin{array}{l}\text { Kaiser-Meyer- } \\
\text { Olkin Measure } \\
\text { of Sampling } \\
\text { Adequacy }\end{array}$} & \multirow{2}{*}{$\begin{array}{l}\text { Bil } \\
\text { Item }\end{array}$} & \multicolumn{3}{|c|}{ Bartlett's Test of Sphericity } \\
\hline & & & $\begin{array}{l}\text { Approx. } \\
\text { Chi- Square }\end{array}$ & df & Sig. \\
\hline $\begin{array}{l}\text { Penerimaan Pelaksanaan } \\
\text { Elemen Penididikan STEM } \\
\text { dalam PdP Guru }\end{array}$ & .971 & 31 & 24523.923 & 465 & .000 \\
\hline
\end{tabular}

\section{Keputusan Bilangan Komponen dan Total Variance Explained}

Jadual 7 menunjukkan keputusan dimensi atau komponen dan Total Variance Explained bagi SSPGSTEM. Jumlah keseluruhan varians bagi mengukur konstruk penerimaan pelaksanaan adalah $68.595 \%$. Keputusan menunjukkan bilangan komponen dan item bagi setiap komponen adalah bersesuaian mengukur konstruk kerana jumlah varians keseluruhan melebihi 60\% (Hair et. al., (2010). Berdasarkan keputusan tersebut, terdapat lima faktor utama yang memberi sumbangan besar kepada perubahan varians secara keseluruhan dalam konstruk penerimaan pelaksanaan. 
Malaysian Journal of Social Sciences and Humanities (MJSSH), Volume 6, Issue 5, (page 64 - 77), 2021

DOI: https://doi.org/10.47405/mjssh.v6i5.793

Jadual 7: Keputusan Bilangan Komponen dan Total Variance Explained SSPG-STEM

\begin{tabular}{clllll}
\hline \multirow{2}{*}{ Component } & \multicolumn{2}{l}{ Extraction Sums of Squared Loadings } & \multicolumn{2}{l}{ Rotation Sums of Squared Loadings } \\
\cline { 2 - 6 } & Total & \% of Variance & Cumulative \% & Total \% of Variance & Cumulative \% \\
\hline 1 & 17.741 & 57.229 & 57.229 & 7.42823 .961 & 23.961 \\
2 & 2.219 & 7.159 & 64.388 & 7.08922 .869 & 46.830 \\
3 & 1.304 & 4.208 & 68.595 & 6.74721 .765 & 68.595 \\
\hline
\end{tabular}

\section{Muatan Faktor Bagi Setiap Item}

Seterusnya, Jadual 1.8 menunjukkan muatan faktor bagi setiap item dalam setiap komponen. Jadual 8 menunjukkan bilangan item setiap komponen telah berjaya diekstrak. Didapati, bilangan item setiap komponen menepati cadangan Pallant (2005), iaitu minimum tiga item untuk menerangkan satu komponen atau faktor. Hair et al. (2010) menetapkan bacaan muatan faktor memenuhi tahap minimum yang dianggap baik, iaitu 0.40 , dan muatan faktor 0.50 atau lebih tinggi, dianggap sangat baik secara praktikal dalam menentukan faktor dalam sesuatu skala pengukuran. Secara keseluruhannya, muatan faktor setiap item berada dalam julat 0.562 hingga 0.799 .

\section{Jadual 8: Muatan Faktor Setiap Item Bagi Konstruk Penerimaan Pelaksanaan Elemen Pendidikan STEM Dalam PdP Guru}

\begin{tabular}{|c|c|c|c|}
\hline \multirow[t]{2}{*}{ Item } & \multicolumn{3}{|c|}{ Component } \\
\hline & 1 & 2 & 3 \\
\hline D16 mengutamakan semangat kerja berpasukan & .741 & & \\
\hline D15 merancang tugasan dengan lebih awal & .730 & & \\
\hline D18 meminta bantuan profesional daripada rakan sekerja & .722 & & \\
\hline D21 berminat melaksanakan PdP & 668 & & \\
\hline D14 bijak membahagikan masa & .668 & & \\
\hline D22 bermotivasi melaksanakan PdP & .650 & & \\
\hline D19 yakin melaksanakan PdP & .643 & & \\
\hline D20 seronok melaksanakan PdP & .641 & & \\
\hline D17 memberi komitmen lebih daripada diperlukan & .640 & & \\
\hline D23 gembira dengan tugas sebagai guru & .609 & & \\
\hline D24 membuat refleksi setiap kali tamat sesi PdP & .562 & & .541 \\
\hline D8 menjalankan penyiasatan dalam suatu perkara & & .799 & \\
\hline D9 pelajar membangunkan model bagi menyelesaikan suatu masalah & & .786 & \\
\hline D7 meneroka masalah dalam dunia sebenar & & .765 & \\
\hline $\begin{array}{l}\text { D12 melakukan proses saintifik (mengumpul, menganalisis, mentafsir dan } \\
\text { mempersembahkan data) }\end{array}$ & & .721 & \\
\hline D3 menyesuaikan pelaksanaan STEM dengan objektif PdP & & .711 & \\
\hline D10 ramalan secara kuantitatif menggunakan disiplin ilmu matematik & & .708 & \\
\hline D5 pelajar membentang hasil produk & & .683 & \\
\hline D6 menguasai isi kandungan pelajaran & & 679 & \\
\hline D4 memupuk nilai-nilai positif & & 639 & \\
\hline D2 PdP yang menggalakkan penglibatan pelajar & & .585 & \\
\hline D32 mendapati PdP yang dijalankan menjadi lebih berkesan & & & .720 \\
\hline D34 mengurangkan tekanan pelajar terhadap peperiksaan awam & & & .712 \\
\hline D33 mampu meningkatkan kemahiran berfikir aras tinggi pelajar & & & .710 \\
\hline D35 mengaplikasi kemahiran generik (kepimpinan dan komunikasi) & & & .707 \\
\hline D31 berupaya meningkatkan aspek pengetahuan pelajar & & & .703 \\
\hline D29 berupaya mengesan penguasaan topik pelajar & & & .702 \\
\hline D30 mempelbagaikan kaedah dalam melaksanakan PdP & & & 677 \\
\hline D28 menjalankan PdP dengan lebih sistematik & .539 & & .661 \\
\hline D25 bersedia dengan sebarang tugasan diberi pentadbir & & & .603 \\
\hline D26 melakukan penambahbaikan dalam penyampaian PdP & .552 & & .600 \\
\hline
\end{tabular}




\section{Ujian Kebolehpercayaan Kajian Rintis}

Keputusan analisis kajian rintis terhadap aras kebolehpercayaan instrumen ditunjukkan dalam Jadual 9. Keputusan ujian kebolehpercayaan mendapati instrumen mempunyai tahap kebolehpercayaan yang baik dan boleh diterima, iaitu a $=0.974$. Bond \& Fox (2007) memerihalkan nilai kebolehpercayaan yang berada pada julat 0.9 sehingga 1.0 disifatkan sebagai sangat baik dan efektif dengan tahap konsistensi yang tinggi dan sesuai digunakan dalam kajian sebenar.

Jadual 9: Analisis Keputusan Ujian Kebolehpercayaan Kajian Rintis

\begin{tabular}{lcc}
\hline \multicolumn{1}{c}{ Instrumen Kajian } & Bil. Item & Cronbach's Alpha \\
\hline $\begin{array}{l}\text { Soal Selidik Penerimaan Pelaksanaan } \\
\text { Elemen Pendidikan STEM Dalam PdP } \\
\text { Guru (SSPG-STEM) }\end{array}$ & 31 & 0.974 \\
\hline
\end{tabular}

\section{Perbincangan}

Keputusan kesahan muka, kesahan kandungan dan kesahan konstruk soal selidik penerimaan pelaksanaan elemen pendidikan STEM dalam PdP guru yang melibatkan pemeriksaan oleh 13 orang pakar didapati sesuai untuk digunakan bagi mengukur konstruk yang dikaji. Seterusnya, analisis faktor yang dijalankan untuk mendapat kesahan konstruk menunjukkan nilai muatan faktor bagi setiap item adalah melebihi 0.50 seperti yang ditetapkan (Hair et al., 2010). Keputusan ini mengesahkan kesemua item adalah sah diguna pakai dalam menjalankan kajian sebenar manakala nilai kebolehpercayaan instrumen adalah, $a=0.974$, iaitu sangat baik dan efektif dengan konsistensi yang tinggi (Bond \& Fox (2007).

\section{Kesimpulan}

Pembangunan dan pengesahan Soal Selidik Penerimaan Pelaksanaan Elemen Pendidikan STEM dalam PdP Guru, telah mengambil kira semakan pakar dalam bidang berkenaan dan disokong dengan hasil analisis. Kesahihan dan kebolehpercayaan soal selidik yang dibangunkan membuktikan soal selidik ini merupakan suatu alat kajian yang mempunyai kesahan dan kebolehpercayaan yang tinggi. Justeru, soal selidik ini boleh digunakan untuk menilai pelaksanaan elemen pendidikan STEM dalam PdP dari aspek penerimaan guru sejak pengenalan PPPM (2013).

\section{Rujukan}

Abdul Zubir Abdul Ghani (2007). Pelaksanaan PBS di kalangan guru Tingkatan 3. Tesis Ijazah Kedoktoran tidak diterbitkan. Universiti Malaya.

Adnan, M. \& Zakaria, E. (2019). Model Pengukuran Kepercayaan Bakal Guru Matematik Di Malaysia. Jurnal Pendidikan Sains dan Matematik Malaysia. 3, 1 (Apr. 2019), 1-11.

Ajzen, I., \& Fishbein, M. (2000). Attitudes and the attitude-behavior relation: Reasoned and automatic processes. In W. Stroebe \& M. Hewstone (Eds.), European review of social psychology (Vol. 11, pp. 1-33). Chichester, UK: Wiley.

Ajzen, I. (1991). Theory of Planned Behaviour. Organization Behaviour and Human Decision Process, 50, 179-211.

Ajzen, I. (2006) Constructing a Theory of Planned Behaviour Questionnaire. Conceptual and Methodological Consideration.

Alkharusi, H. (2009). Correlates of Teacher Education Students' Academic Performance in an Educational Measurement Course. International Journal of Learning 16: 1-15.

Azodi, D. (2006). Principal Leadership, Trust and Teacher Efficacy. [Disertasi EdD. Sam Houston State University]. 
Bahagian Pembangunan Kurikulum. (2016). Panduan Pelaksanaan Sains, Teknologi, Kejuruteraan dan Matematik (STEM) dalam Pengajaran dan Pembelajaran. Kementerian Pendidikan Malaysia.

Bekiroglu-Ogan, Feral. (2009). Assessing Assessment: Examination of Pre-Service Physics Teachers' Attitudes towards Assessment and Factors Affecting Their Attitudes. International Journal of Science Education, v31 n1 p1-39.

Berita Harian. (2019, 17 Mac). Ibu bapa beri isyarat salah antara punca STEM merosot. Berita Harian. Diperolehi daripada: https://www.bharian.com.my/berita/pendidikan/2019/03/541952/ibu-bapaberi-isyarat-salah-antara-punca-stem-merosot

Blenkin, G.M., Edwards, G., \& Kelly, A.V. (1992). SAGE Publications.

Bond T. \& Fox C.M. (2007). Applying the Rasch Model Fundamental Measurement in the Human Sciences. Ed. ke-2. Lawrence Erlbaum Associates.

Bunyamin, M. A. H., \& Finley, F. (2016). STEM Education in Malaysia: Reviewing the Current Physics Curriculum. Kertas kerja yang telah diterima untuk pembentangan dalam International Conference of Association for Science Teacher Education (ASTE), 7-9 Januari 2016 di Nevada, Amerika Syarikat.

Che Mas Saud, Bainah Mustafa, Fazidah Mohamad Nor, Nur Fatini Mohd Basri, Nur Nabilah Mohd Basri. (2017). Kemahiran Berfikir Dan Pelaksanaan Dalam Pengajaran Guru-Guru Sekolah. Prosiding Persidangan Penyelidikan Dan Inovasi Pendidikan Kebangsaan Kali Ke Dua Tahun 2017. (11-12 Okt 2017). 442-450.

Chiu, A., Price, A., Ovrahim, E. (2015). Supporting Elementary and Middle School Stem Education at The Whole-School Level: A Review of The Literature. NARST 2015 Annual Conference.

Chua, Y.P. (2014). Kaedah penyelidikan: Kaedah dan statistik penyelidikan (3rd ed.). Shah Alam: McGraw-Hill.

Cohen, D. K., Raudenbush, S. W., \& Ball, D. L. (2003). Resources, instruction, and research. Educational Evaluation and Policy Analysis, 25(2), 119-142.

Coleman, J., (1990). Foundations of Social Theory. Harvard University Press.

Constant, D., Kiesler, S., \& Sproull, L. (1994). What's Mine is Ours, or Is it? A Study of Attitudes about Information Sharing. Information Systems Research (5:4), pp. 400-421.

Copriady, J. (2014). Teachers Competency in the teaching and learning of chemistry practical. Mediterranean Journal of Social Sciences.

Curriculum Development Centre. (2016). Implementation Guide for Science, Technology, Engineering, and Mathematics. Ministry of Education Malaysia.

Dede, C. (2010). Comparing frameworks for 21 st century skills. In J. Bellance, \& R. Brandt (Eds.), 21st century skills: Rethinking how students learn (pp. 51-76). Bloomington, IN: Solution Tree Press.

Demetriadis, S., Barbas, A., Molohides, A., Palaigeorgiou, G., Psillos, D., Vlahavas, I., Tsoukalas, I. \& Pombortsis, A. (2003). Cultures in Negotiation: Teachers' acceptance/resistance attitudes considering the infusion of technology into schools. Computer Education, 41, pp. 19-37.

Ernest, P. (1989). The knowledge, beliefs and attitudes of the mathematics teacher: A model. Journal of Education for Teaching, 15(1), 13-33.

Fishbein, M \& Ajzen, I. (1975). Beliefs, Attitudes, Intentions and Behaviors. Adison Wesley Publishing Company.

Fishbein, M \& Ajzen, I. (1980). Understanding Attitudes and Predicting Social Behavior. PrenticeHall.

Fives, H., \& Buehl, M. M. (2012). Spring cleaning for the messy construct of teacher beliefs: What are they? Which have been examined? What can they tell us? In K. R. Harris, S. Graham \& T. Urdan (Eds.), APA Educational Psychology Handbook (Vol. 2, pp. 471-499). Washington DC: APA.

Fives, H. \& Buehl, M. M. (2014). Exploring differences in practicing teachers' valuing of pedagogical knowledge based on teaching ability beliefs. Journal of Teacher Education, 65(5), 435-448.

Frey, N., \& Fisher, D. (2004). School Change and Teacher Knowledge: A Reciprocal Relationship. Teacher Education and Special Education, 27(1), 57-67.

Fullan, M, \& Mascall, B. (2000). Human resource issues in education. A literature review. Report prepared for the New Zealand Ministry of Education. Ministry of Education.

Fullan, M. (2001). Leading in a Culture of Change. Jossey-Bass. 
Guskey. T.R. (2002). Professional Development and Teacher Change. Teachers and Teaching: theory and practice, Vol. 8, No. 3/4, 2002.

Hair, J. F., Black, W. C., Babin, B. J., \& Anderson, R. E. (2010). Multivariate data analysis (7th ed.). Prentice Hall.

Hall, G. E., \& Hord, S. M. (2001). Implementing change: Patterns, principles, and potholes. Allyn \& Bacon.

Hamzah, M.O \& Sinnasamy, P. (2009). Between the Ideal and Reality: Teachers Perception of The Implementation of School Based Oral English Assessment. In the English Teacher 38: 13-29.

Han, S., Yalvac, B., Capraro, M. M., \& Capraro, R. M. (2015). In-service Teachers' Implementation and Understanding of STEM Project Based Learning. Eurasia Journal of Mathematics, Science dan Technology Education 11(1).

Hurlock, E. B. (1978). Child Development. Kosaido Publishing Co. Ltd.

Johnson, C. C., \& Sondergeld, T. A. (2016). Effective STEM professional development. In C. C. Johnson, E. E. Peters-Burton, \& T. J. Moore (Eds.), STEM road map: Aframework for integrated STEM education (pp. 203-210). Routledge Taylor \& Francis Group.

Kagan, S. (1992). Cooperative Learning. Resources for Teachers.

Kaiser, H. F. (1974). An index of factorial simplicity. Psychometrika, 39, 31-36.

Kelly, A. V. (1982). The Curriculum: Theory and Practice (2nd ed.). Harper \& Row.

Kementerian Pendidikan Malaysia (2013). Pelan Pembangunan Pendidikan Malaysia 2013-2025. Kementerian Pendidikan Malaysia.

Kementerian Pendidikan Malaysia KPM. (2016). Laporan Tahunan Pelan Pembangunan Pendidikan Malaysia 2013-2025. Kementerian Pelajaran Malaysia (KPM).

Kementerian Pendidikan Malaysia KPM. (2018). Laporan Tahunan Pelan Pembangunan Pendidikan Malaysia 2013-2025. Kementerian Pelajaran Malaysia (KPM).

Khuzaimah Zaaim, Mohamed Yusoff Mohd Nor, Shahlan Surat. (2019). Tahap Kompetensi Guru (PdPc) SKPMG2 Dan Tahap kemenjadian Murid. International Journal of Education, Psychology and Counseling, Vol 4 Issues 27, pp.51-62.

Kulbertis, G. (2006). Leadership That Builds Trust: Implications for New Principals. [Disertasi EdD, Central Michigan University].

Kulkarni, U. R., Ravindran, S., \& Freeze, R. (2006). A Knowledge Management Success Model: Theoretical Development and Empirical Validation. Journal of Management Information Systems, 23(3), 309-347.

Law, Y. (2008). Effects of Cooperative Learning on Second Graders' Learning. From Text. Educational Psychology, 28, 567-582.

Likert, R. (1932). A technique for the measurement of attitudes. Archives of Psychology, 22 140, 55.

Lokman Mohd Tahir \& Hamidon A. Rahman. (2007). Tahap Kepercayaan Pentadbir Sekolah Rendah Terhadap Guru: Satu Penilaian. Prosiding Simposium ASEMAL 5 (Educational dan Leadership). Anjuran Sekolah Kognitif dan Pendidikan, Universiti Utara Malaysia di Hotel Legend, Kuala Lumpur.

Lokman Mohd Tahir, Mohd Anuar Abd Rahman, M. Al-Muzammil Yassin \& Phoon Ai Ling. (2010). Penilaian Guru Sekolah Rendah Terhadap Peranan Guru Besar Sekolah Sebagai Pemimpin Teknologi Maklumat Dan Komunikasi (Ict). Asia Pacific Journal of Educators and Education, Vol. 25, 169-188.

Louis, K. S. (1998). Effects of teacher quality of work life in secondary schools on commitment and sense of efficacy. School Effectiveness and School Improvement, 9, 1-27.

Malaysian Science and Technology Information Centre (MASTIC). (2008). National Survey of Research and Development (R\&D). Diperolehi daripada: https://mastic.mestecc.gov.my/stisurvey-content-spds/national-survey- research-and-development-rd-2008

Miller, M.D., Robert, L.L., dan Norman, E.G. (2009). Measurement and assessment in teaching. 5th edition. Pearson International Edition, New Jersey: Upper Saddle River.

Misha, A. (1996). Organizational Responses to Crisis: The Centrality of Trust. In R. Kramer \& T. Tyler (Eds) Trust in Organization. Sage.

Mohammad Azri Bin Amatan \& Crispina Gregory K. Han. (2019). Pengaruh Persekitaran Psikososial Sekolah dan Efikasi Kendiri Guru Terhadap Amalan Pengajaran dan Pembelajaran Abad Ke-21. International Journal of Education, Psychology and Counseling, Counseling, 4 (32), 284-314. 
Mohd Nasaruddin Basran. (2006). Perlaksanaan Kurikulum Bahasa Melayu. [Tesis yang tidak diterbitkan, Universiti Malaya].

Nadelson, L., Briggs, P., Bubak, K., Fuller, M., Hammons, D., \& Sass, M. (2012). The tension between teacher accountability and flexibility: The paradox of standards-based reform. Teacher Education and Practice, 25(2), 196-220.

Noorzeliana Idris (2016). Penilaian Pelaksanaan Pentaksiran Berasaskan Sekolah Dalam Kalangan Guru. [Tesis PhD, Fakulti Pendidikan dan Pembangunan Manusia. Universiti Pendidikan Sultan Idris].

Noradzimah Abdul Majid, Harizon Suffian \& Liew Phaik Hoon. (2017). International Conference on Global Education, Common Wealth, and Cultural Diversity. Universitas Ekasakti, Padang, 10 11 April 2017.

Noraini Mat Loddin \& Suhaida Abdul Kadir. (2013). Penerimaan Guru Terhadap Pentaksiran Berasaskan Sekolah (PBS) Dengan Komitmen Guru Dalam Melaksanakan PBS Sekolah Rendah, Seminar Pasca Siswazah Dalam Pendidikan (Greduc 2013).

Noraini Idris. (2019, 18 Mar). Experts: Fewer STEM students will affect nation's talent pool. The Star Online. Diperolehi daripada https://www.thestar.com.my/news/nation/2019/03/18/experts-fewer-stem- $\quad$ students-will-affectnations-talent-pool

Nunnally, J. C. (1967). Psychometric Theory. McGraw-Hill.

Nur Amelia Adam \& Lilia Halim. (2019). Cabaran Pengintegrasian Pendidikan STEM Dalam Kurikulum Malaysia. Seminar Wacana Pendidikan 2019 (SWAPEN 2.0).

Nur Hidayah Alawi \& Tuan Mastura Tuan Soh. (2018). Kaedah Pembelajaran Berasaskan Projek Bagi Meningkatkan Tahap Kemahiran Berfikir Kritis Murid Tingkatan 4 Topik Ekosistem Dinamik. Prosiding Seminar Kebangsaan Majlis Dekan Pendidikan Universiti Awam 2018. Penyunting: Rahimah Embong, Hanif Md Lateh @ Junid, Mustafa Che Omar, Mohamad Zaidin Mohamad \& Abdul Hakim Abdullahe. ISBN 978-967-2231-03-5 (2018).

OECD (2014). PISA 2012 Results: What Students Know and Can Do - Student Performance in Mathematics, Reading and Science (Volume I, Revised edition, February 2014), PISA, OECD Publishing, Paris.

Olson, M. (2000). The centrality of teachers' narratives in curriculum. Canadian Journal of Education, 25(2), 169-179.

Pallant, J. (2005). SPSS Survival Guide A Step by Step Guide to Data Analysis Using SPSS for Windows. 3rd Edition, Open University Press, New York.

Pryor, B. W., Pryor, C. R., \& Kang, R. (2015). Teachers' thoughts on integrating STEM into social studies instruction: Beliefs, attitudes, and behavioral decisions. The Journal of Social Studies Research.

Radin Mohd Shamsul Zahri. (2008). Penilaian program pentaksiran kerja kursus berasaskan sekolah Teknologi kejuruteraan SPM. [Tesis Ijazah Sarjana yang tidak diterbitkan, Univerisiti Kebangsaan Malaysia].

Ramlah Hamzah. (1993). Persepsi Dan Masalah Guru-Guru Terhadap Mata Pelajaran Kemahiran Hidup. Jurnal Pendidikan Guru, Bil.9, 50-69.

Reio, T.G. (2005). Emotions as a Lens to Explore Teacher Identity and Change: A Commentary. Teaching and Teacher Education, 21(8): 985-993.

Rohani Arbaa, Hazri Jamil dan Nordin Abd. Razak (2010). Hubungan Guru-Pelajar dan Kaitannya dengan Komitmen Belajar Pelajar: Adakah Guru Berkualiti Menghasilkan Perbezaan Pembelajaran antara Jantina Pelajar. Jurnal Pendidikan Malaysia 35(2) (2010): 61-69.

Rohani Arbaa, Hazri Jamil dan Nordin Abd. Razak (2010). Hubungan Guru-Pelajar dan Kaitannya dengan Komitmen Belajar Pelajar: Adakah Guru Berkualiti Menghasilkan Perbezaan Pembelajaran antara Jantina Pelajar. Jurnal Pendidikan Malaysia 35(2) (2010): 61-69.

Rosezalvia Dennis. (1996). Kesediaan Mahasiswa Sarjana Muda Teknologi Serta Pendidikan (Kemahiran Hidup) Mengajar Mata Pelajaran Reka Bentuk Teknologi. [Project Paper (Sarjana Muda Sains serta Pendidikan Kemahiran Hidup, Universiti Teknologi Malaysia].

Rosli Yacob (2008). Bahagian Pendidikan Guru. Dalam Bahagian Pendidikan Guru, Sejarah Perguruan Malaysia, hlm 204-216. Putrajaya: Kementerian Pelajaran Malaysia.

Ruddock, J. Chaplain, R. dan Wallace, G. (1995). School Improvement: What Can Pupils Tell Us? David Fulton. 
Rummers \& Gage. (1987) dalam Azri Bin Mokhtar @ Ahmad. (2016). Penilaian Program Pendidikan Moral Dan Etika Tentera Dalam Angkatan Tentera Malaysia. [Tesis PhD, Universiti Malaya].

Shepard, L.A. (2000). The Role of Classroom Assessment in Teaching and Learning, CSE Report 517, Centre for the Study of Evaluation, Graduate School of Education \& Information Studies. University of California USA.

Shumow, L. \& Miller, J.D. (2001). Parents' at-home and at-school academic involvement with young adolescents. Journal of Early Adolescence, 21(1): 68-91.

Siew, N. M., Amir, N., \& Chong, C. L. (2015). The perceptions of pre-service and inservice teachers regarding a project-based STEM approach to teaching science. Springer Plus, 4(1), 1-20.

Siti Hajar Halili \& Suguneswary. (2016). Penerimaan Guru Terhadap Penggunaan Teknologi Maklumat Dan Komunikasi Berasaskan Model Tam Dalam Pengajaran Mata Pelajaran Bahasa Tamil. Jurnal kurikulum \& Pengajaran Asia Pasifik, April 2016, Bil. 4.

Stenhouse, L. (1975). An Introduction to Curriculum Research and Development. Heinemann.

Stenhouse, L. (1984). Evaluating curriculum evaluation. In C. Adelman (Ed.). The politics and ethics of evaluation, pp. 77-86. Croom Helm.

Stiggins, R. (2005). From formative assessment to assessment for learning A path to success in standards-based schools. Phi Delta Kappan, 87, 324-328.

Strike, K. (2007). Ethical Leadership in Schools. Teachers College Press.

Stufflebeam, D.L. (1987). Professional Standards for Assuring the Quality of Educational Program and Personnel Evaluations. International Journal of Educational Research, 11(1), 125-143.

Stufflebeam, D. L. (2001). Evaluation Checklists: Practical Tools for Guiding and Judging Evaluations. American Journal of Evaluation, 22(1), 9.

Suresh Kumar. N Vellymalay. (2011) Sikap dan tingkah laku remaja terhadap pembelajaran. Jurnal Pendidikan Malaysia, 36 (2). pp. 25-32.

Syed Ismail Syed Mustafa, (2013) Amalan Bimbingan Pengajaran Pensyarah Dan Guru Pembimbing Dalam Program Mentoring Praktikum Serta Impaknya Terhadap Kualiti Guru Pelatih. Jurnal Pendidikan Malaysia, 38 (1). pp. 71-78.

Tabachnick, B. G., \& Fidell, L. S. (1996). Using Multivariate Statistics (3rd ed.). Harper Collins.

Taha Abdul Kadir. 1977. Persekitaran rumah tangga dan Pencapaian Akademik Murid-murid di Sekolah Menengah Kebangsaan. Tesis Sarjana Pendidikan. University Malaya: Kuala Lumpur.

Tan Ai Mei. (2010). Pentaksiran Berasaskan Sekolah (PBS) di Malaysia. Kesediaan Guru, Isu dan Panduan Pelaksanaan. Gerak Budaya Enterprise. [Tesis Doktor Falsafah, Universiti Kebangsaan Malaysia].

Tang, Keow Ngang, dan Sulermutyrean, Thanaletchumy. (2015). Kemahiran insaniah guru dan penglibatan guru dalam membuat keputusan pengurusan sekolah. Sains Humanika, 4(1), 75-82.

Thompson, A. G. (1992). Teachers' Beliefs and Conceptions: A Synthesis of The Research. In D. A. Grouws (Ed.), Handbook of research on mathematics teaching and learning: A project of the National Council of Teachers of Mathematics (p. 127-146). Macmillan Publishing Co, Inc.

Thorndike, R. M. (1997). The Early History of Intelligence Testing. In D. P. Flanagan, J. L. Genshaft, \& P. L. Harrison (Eds.), Contemporary intellectual assessment: Theories, tests, and issues (p. 316). The Guilford Press.

Tschannen- Moran, Megan. (2003). Fostering Organizational Citizenship Behavior in Schools: Transformational Leadership and Trust. Miskel, C dan Hoy, W., Studies in Leading and Organizing Schools. Information Age Publishing.

Walker, S., \& Fraser, B. (2005). Development and validation of an instrument assessing distance education learning environments in higher education: the distance learning environment survey (DELES). Learning Environments Research: An International Journal, 8(3), 289-308.

Yusof, N., Hashim, R. A., Badusah, J., Konting, M. M., \& Kian, C. K. (2012). Communicating Change: The Five Sentiments of Change Perspective. Jurnal Pengurusan, 35, 87-96.

Zimbardo, P. G., \& Leippe, M. R. (1991). Mcgraw-Hill Series in Social Psychology, The Psychology of Attitude Change and Social Influence. Mcgraw-Hill Book Company.

Zul Aizam Yassin, Wan Azlan Wan Ismail, Hasmadi Ghaza, Wan Roslan Wan Ramli. (2017). Penilaian Tahap Kecergasan Fizikal Calon Guru Dalam Ujian Kecergasan Fizikal Institut Pendidikan Guru Malaysia. Prosiding Persidangan Penyelidikan Dan Inovasi Pendidikan Kebangsaan Kali Ke Dua Tahun 2017. 
DOI: https://doi.org/10.47405/mjssh.v6i5.793

Zulkifli Abdul Manaf \& Raja Maznah Raja Hussain. (1994). Attitudes, Knowledge and Previous Computer Experience of Teacher Trainees in The Diploma of Education Programme at the University of Malaya. Journal of Educational Research, 16: 1-19. 